\title{
Review
}

\section{A short history of insecticides}

\author{
Volodymyr Volodymyrozych Oberemok', Kateryna Volodymyrivna Laikova², Yuri Ivanovich Gninenko3, \\ Aleksei Sergeevich Zaitsev ${ }^{1 *}$, Palmah Mutah Nyadar ${ }^{1}$, Tajudeen Adesoji Adeyemi ${ }^{1}$
}

\author{
${ }^{1}$ Taurida National V.I. Vernadsky University, Academician Vernadsky Ave. 4, 95007 Simferopol, Ukraine \\ ${ }^{2}$ Crimea State Medical S.I. Georgievsky University, Lenin Ave. 5/7, 95006 Simferopol, Ukraine \\ ${ }^{3}$ All-Russian Research Institute for Silviculture and Mechanization of Forestry, Institutskaya Street 15, Pushkino 141200, Russia
}

Received: April 12, 2015

Accepted: June 29, 2015

\begin{abstract}
This review contains a brief history of the use of insecticides. The peculiarities, main advantages, and disadvantages of some modern insecticides are described. The names of the discoverers of some of the most popular insecticide preparations on the world market, are listed. The tendencies to find new insecticides to control the quantity of phytophagous insects are discussed. Special attention is paid to the perspective of creating preparations based on nucleic acids, in particular DNA insecticides. The use of insect-specific, short single-stranded DNA fragments as DNA insecticides, is paving the way in the field of "intellectual" insecticides that "think" before they act. It is worth noting, though, that in the near future, the quantity of produced insecticides will increase due to the challenges associated with food production for a rapidly growing population. It is concluded, that an agreeable interaction of scientists and manufacturers of insecticides should lead to the selection of the most optimal solutions for insect pest control, which would be safe, affordable, and effective at the same time.
\end{abstract}

Key words: biological preparations, chemical insecticides, crop protection, DNA insecticides

\section{Introduction}

People engaged in agricultural practices usually face a harvest management problem due to loss caused by a variety of insect pests. It may be impossible to say who decided to apply insecticides first, but apparently it happened a very long time ago. It could have been a farmer who thought about protecting his crops from pest insects. In any case, the very first control means, for controlling pest insects, were prompted by nature itself. People noticed the negative effects of natural compounds on various insects and used the natural compounds in everyday life.

\section{From ancient sulfur and pyrethrum to synthetic} insecticides and DNA insecticides

Botanical preparations seem to have been the first substances used as insecticides by ancient people. For example, Dalmatian pyrethrum flowers contain up to $1.5 \%$ of pyrethrin (active insecticidal substance). This ingredient was used as an insecticide in ancient China and then in the Middle Ages in Persia (Davies et al. 2007). In Europe, dried, ground Dalmatian pyrethrum possessing extermination properties against cockroaches, bedbugs, flies, and mosquitoes, was known more than 200 years ago thanks to the Armenian merchants who were selling it as Persian powder ("Persian dust", "insect powder") (Davies et al.
2007). Some other plants are also used as popular insecticides (Isman 2006). For example, elderberry flowers are effectively used against cockroaches (Dagaev 1997), aqueous extract of tobacco against aphids (Sohail et al. 2012), and an aqueous extract of wormwood against weevils (Ignatowicz and Wesołowska 1994).

Since 1000 BC, people used natural chemicals in the struggle against pest insects. Inorganic sulfur (via fumigation) was one of these natural chemicals. Homer wrote in "The Iliad and The Odyssey" about the "divine cleansing" ritual using sulfur which helped to get rid of lice. In the $900 \mathrm{~s} A D$, arsenics began to be used, later lead arsenate $\left(\mathrm{PbHAsO}_{4}\right)$ and cryolite $\left(\mathrm{Na}_{3} \mathrm{AlF}_{6}\right)$ as cellular poisons, and borax $\left(\mathrm{Na}_{2} \mathrm{~B}_{4} \mathrm{O}_{7}\right)$ as a dehydrator, were used in insect baits (Popov et al. 2003).

A wider use of plant protection chemicals started to be used in the middle of the 19th century. In the struggle against the Colorado potato beetle, Paris green (mixed copper acetoarsenite) was successfully applied in 1871 (Alyokhin 2009). Paris green was widely used in many countries around the world until the middle of the 20th century, in particular for the control of the malaria vectors; mosquitoes of the genus Anopheles (Symes 1952; Majori 2012).

In 1874, the Austrian student and chemist Othmar Tseidler, synthesised DDT; probably the most-known 
chemical insecticide (Bate 2007). Its insecticidal properties were found in 1939 by Swiss chemist Paul Müller working at that time in J. R. Geigy Ltd. (Davies et al. 2007). In 1948, P. Müller won the Nobel Prize in Medicine "for the discovery of the high efficiency of DDT as a contact poison". As it turned out later, DDT was effective in action and dangerous not only against pest insects but also for many other groups of organisms, such as mammals, birds, and reptiles.

The era of DDT in plant protection, lasted until the second half of the 20th century when it was replaced by a period of widespread use of organophosphates (dichlorvos, cyanophos, fonofos etc.) and carbamates (carbaryl, carbofuran, aldicarb etc.). Despite harming the environment with carbamates and organophosphates, these insecticides are still among the most widely used classes of preparations (19\% of the world market) and play a major role in the control of pest insects (Casida and Durkin 2013). It should be noted, that production of carbaryl is connected to the biggest man-made disaster that has ever happened in the world. The disaster took place in Bhopal (India), in 1984. An explosion at the Union Carbide Corporation plant released toxic methyl isocyanate that killed about 3800 people the first day (Broughton 2005).

After synthesis of allethrin in 1949, pyrethrins were restored as insecticides, because based on them the first generation of pyrethroids appeared. Having low toxicity to those who were warm-blooded, pyrethroids quickly gained popularity among people who cared about their health. On the global market of insecticides in the early 1970s, permethrin, cypermethrin, and deltamethrin had a serious drawback; namely that they relatively quickly lost activity in the environment when in contact with ultraviolet light. Though this property of the pyrethroids complicated their application, it helped to prevent the accumulation of pyrethroids in the environment. Therefore, this class of insecticides still finds wide application in plant protection. Currently, pyrethroids constitute 17\% of the global insecticide market (Davies et al. 2007).

Today the most popular insecticides are neonicotinoids (Yamamoto 1999; Goulson 2013). They act by systematically moving in the plant tissues and protecting all parts of the plant. Acting as neurotoxins for most arthropods they provide effective control of insect pests (Goulson 2013). Neonicotinoids irreversibly bind the nicotinic acetylcholine receptors to produce overstimulation of nerve cells, which paralyses the insect. The very first neonicotinoid that appeared on the insecticide market was imidacloprid. It was registered as «Hachikusan» in Japan in 1993. Imidacloprid is now the most frequently used insecticide in the world (Yamamoto 1999; Jeschke et al. 2011). Over the past 20 years, the market of neonicotinoids has expanded. It is now possible to find a large number of represented neonicotinoids, such as acetamiprid, thiamethoxam, dinotefuran, and thiacloprid. In 2008, the neonicotinoids comprised $24 \%$ of the global insecticide market (Jeschke et al. 2011). Neonicotinoid insecticides are successfully applied to control pests in a variety of agricultural crops. It must be noted that neonicotinoids may not only affect insect pests but also non-target organisms e.g. pollinators, including the honey bee (Blacquière et al. 2012).

The search for new insecticides and the improvement of old ones continues today. Almost all species of insects develop resistance to applied insecticides. This fact pushes scientists to create new preparations. A lot of new chemical insecticides are now being elaborated on and are appearing on the market. Examples of such insecticides are: phenylpyrazoles, pyrethroids of 4th generation, avermectins, diamides, spinosyns, also there are insect growth regulators, pyrazole insecticides, macrocyclic lactone insecticides, formamidine insecticides (amitraz), botanical insecticides (e.g. azadirachtin) etc. The onset of the post-genomic period of plant protection led to the emergence of new opportunities to create new preparations. For example, baculoviruses are being genetically modified to accelerate their action on insect pests (Inceoglu et al. 2006; Rosell et al. 2008). Recombinant (Federici et al. 2010) and more efficient serotypes of entomopathogenic bacteria are being created. Genetically modified plants synthesising bacterial toxins (cry proteins) within the plant cell are being produced (Sanchis 2011).

The newest insecticides can be grouped into the following classes:

\section{Macrocyclic lactones (avermectins and milbemycins)}

This class comprises natural and semi-synthetic, 16-membered macrocyclic lactones (Khalil 2013). They affect cells by inhibiting the flow of chloride ions. This process shuts down the electrical impulses in the nerve cells of their target organisms. The naturally occurring novel macrocyclic lactones are avermectins, emamectin benzoate, and milbemycin. The whole family of macrocyclic lactones displays an unprecedented potency against mites and insects as well as nematodes. Avermectin is used on various crops such as citrus, pome fruits (for example, apples and pears), vegetables, and cotton. The products are non-systemic and are removed relatively rapidly from the environment after application. In human organism, avermectin has been reported to block LPS-induced secretion of the tumor necrosis factor, nitric oxide, prostaglandin E2, and also blocks an increase of intracellular concentration of calcium ions (Viktorov and Yurkiv 2003).

\section{Phenylpyrazoles}

A well-known member of this class of insecticides is fipronil. Fipronil can be applied to the foliage, soil, and seeds. Fipronil is a broad-spectrum insecticide that disrupts an insect's central nervous system by blocking GABA-gated ( $\gamma$-Aminobutyric acid) chloride channels and glutamategated chloride $(\mathrm{GluCl})$ channels, resulting in central nervous system toxicity. However, it has a limited ability to translocate through the plant. Fipronil acts on insect pest species such as the Lepidoptera (moths), Coleoptera (beetles), and Diptera (flies, mosquitoes). It is also used to control urban pests such as ants and cockroaches, and is also effective in controlling termites. In animal health care, they are used on cats and dogs to combat ticks and 
fleas. However, Fipronil is known to be highly toxic to fish, aquatic invertebrates, and bees.

\section{Nereistoxin analogues}

Much research has been done to finding chemicals, which will inhibit the nicotinic acetylcholine receptor (nAChR) from functioning correctly. The first examples of these insecticides are cartap, thiosultap, bensultap, and thiocyclam. They break down either by action of water or light to produce the toxin which is called nereistoxin; a substance that was first isolated from the naturally occurring marine nereid worm Lumbrineris heteropoda. Nereistoxin acts by effectively paralysing the insect pest.

\section{Neonicotinoids}

The neonicotinoids are another group of insecticides which affect the nicotinic acetylcholine receptor. The neonicotinoids are now the fastest growing group of insecticides and one of the major classes of insecticides in insect pest management. They are active against a broad range of insect pests, and exhibit activity through both oral (ingestion) and contact routes of application. They have a high level of efficacy, and a favorable environmental and toxicological profile. This has led to their rapid adoption in numerous agricultural areas for quick control of a broad range of chewing and sucking pests. Neonicotinoids are said to have a minimum impact on beneficial insects. This group of insecticides acts on and overstimulate the insect's central nervous system (Gordana and Janko 2013). Examples of neonicotinoids are: imidacloprid, thiamethoxam, clothianidin, thiacloprid, and acetamiprid.

\section{Diamides}

This is a new class of insecticides, which includes the phthalic acid diamides and the anthranilic diamides (chlorantraniliprole). Diamides potently activate the ryanodine receptor, releasing stored calcium from the sarcoendoplasmic reticulum causing impaired regulation of muscle contraction. (Qi et al. 2013). A good example of a phthalic acid diamide is flubendiamide. An example of anthranilic diamide is chlorantraniprole. It is marketed under several names, one of which is Rynaxypyr. Diamides protect fruit and vegetables from beetles, weevils, leaf miners, and caterpillars. They act on the ryanodine receptors of vertebrates very weakly, most probably explaining their excellent toxicological profile, being specific to the insect pests and relatively non-toxic to mammals, fish, and birds.

\section{Benzoylureas}

Benzoylureas have been developed and used as commercial insect growth regulators (IGRs) acting by inhibiting the biosynthesis of chitin (Msangi et al. 2011). Diflubenzuron was one of the first of this class to be used commercially. It is used for the control of chewing insects and coleopteran pests (beetles and weevils) in fruit, cotton, soybeans, and vegetable crops.
Due to their relative non-toxic nature to vertebrates, benzoylureas, such as lufenuron and triflumuron, are also used in veterinary medicine and in the home against animal and human health pests such as fleas, ticks, and cockroaches. It is important to note, though, that benzoylureas possess a high potential for bioaccumulation in the food chain, and benzoylureas are a high risk to aquatic organisms.

\section{Cyclic ketoenols}

They are a new chemical class of insecticides affecting development by inhibiting acetyl-CoA-carboxylase and subsequent lipid biosynthesis (Nojumian et al. 2015). An example of this class is spirodiclofen that has excellent long-lasting efficacy. Spirodiclofen is effective in early to late season applications for mite/insect control. Spirodiclofen is being developed for worldwide use in pome fruit (e.g. apples, pears), stone fruit, citrus fruit, grapes, almonds, and nuts; being very effective against mites. Spiromesifen is a new foliar contact acaricide and has been used worldwide on vegetables, fruits, cotton, corn, beans, tea, and some ornamentals.

Chemical insecticides were largely influenced by the development of chemistry. In addition to chemical insecticides, biological preparations have been in use as well. Louis Pasteur and Ilya Metchnikov were the first to use microbiological preparations in insect pest control in the 1870s (Sanchis 2011). In practice the most commonly used biological preparations are of bacterial, viral, and fungal origin.

\section{Bacterial agents}

Among the bacterial agents, an important role is played by the Gram-positive, ubiquitous, spore-forming soil bacterium Bacillus thuringiensis. The first successful attempt to use preparations based on $B$. thuringiensis was made in the late 1920s on the gypsy moth in the United States (Metalnikov and Chorine 1929). For plant protection, the endospores of the bacterium as well as its diamondshaped crystal protein endotoxins (cry proteins) are being used against different groups of insect pests. Cry proteins have a high specificity in their action on the target insects (Lepidoptera, Diptera, Coleoptera, Hymenoptera) while they are harmless to vertebrates as well as other insects (De Maagd et al. 2001). In today's market, there are a lot of insecticide-like preparations based on B. thuringiensis, namely "Biobit", "Agree", "Crymax", "Lepinox", and "Novodor". These products, based on B. thuringiensis, constitute $75 \%$ of the market of biological preparations and $4 \%$ of all insecticides (Sanchis 2011). As far as bacterial preparations are concerned, the more complex the structure of the insecticidal agent - the more selective it is in action, and the more expensive it is to produce. Viral preparations are not an exception to this rule.

\section{Viral agents}

Almost all registered viral preparations that are used to protect plants are based on baculoviruses (Bahvalov 
2001; Szewczyk et al. 2006). Baculoviruses started to be used widely as insecticides after the application of the nuclear polyhedrosis virus against alfalfa caterpillars by the American microbiologist Edward Steinhaus, in 1945 (Tarasevich 1985). Subsequently, viral preparations have proven to be expensive and selective, acting effectively but slowly (Rosell et al. 2008). The slow action of baculoviruses is associated with a latent period in the life cycle of the virus when it has to "look around" in the cell. Baculoviruses are represented by two phenotypes, namely the budded virus and the occlusion-derived virus. The budded virus transmits viral infection from cell to cell whereas the occlusion-derived virus transmits infection from insect to insect (Jehle et al. 2006). The process of polyhedra formation continues until the cell nucleus is completely filled with them; as a consequence, one larva may contain around $10^{10}$ polyhedra representing more than $30 \%$ of the dried biomass of the insect (Miller et al. 1983). Viral polyhedra are composed of virions embedded in a matrix of the polyhedrin protein which is highly resistant to various environmental factors (Chiu et al. 2012). Baculoviral preparations are made based on viral polyhedra to cause oral infection of phytophagous insects. The use of baculoviral preparations lag significantly behind that of preparations based on B. thuringiensis (Moscardi et al. 2011).

\section{Fungal agents}

Nowadays, fungi are not often used as insecticides, compared to other chemical pesticides, due to the fact that fungal agents are slow in action and rather inconsistent in use. They have the advantage of being cheap and of having little adverse effect on the environment as compared to some chemical insecticides. In recent years, crop protection management has also looked into integrated pest management through the use of fungi. Approximately 750 species of fungi are pathogenic to insects. Generally, those fungi used as an insecticide include: Beauveria bassiana, Metarhizium anisopliae, Nomuraea rileyi, Vericillium lecanii, Lagenidium giganteum, and Hirsutella thompsonii (Chakoosari 2013).

\section{DNA insecticides}

Entirely new approaches are now used to control insect pests. One of them is the creation of insecticides based on nucleic acids. In particular, there are the DNA insecticides based on short single-stranded fragments of antiapoptotic (IAP) genes of nuclear polyhedrosis viruses (Oberemok 2008a; Oberemok 2011; Simchuk et al. 2012; Oberemok et al. 2013a, b; Oberemok and Skorokhod 2014; Oberemok and Nyadar 2015; Oberemok et al. 2015), and formulations based on long double-stranded RNA fragments (Wang et al. 2011; Gu and Knipple 2013). The idea of the development and application of such preparations is similar to methods of blocking the expression of genes important for life using the mechanisms of RNA interference (Fire et al. 1998; Wang et al. 2011) and DNA interference (Kawai-Toyooka et al. 2004) and application of antisense technologies (Weiss et al. 1999; Lu et al. 2004). The first practical results in this direction show the potential of the insecticidal preparations based on nucleic acids. It was Oberemok and Skorokhod (2014) who showed that the insecticidal potential of the viral DNA fragments can be used to create safe, relatively inexpensive, and fastacting DNA insecticides to control the quantity of gypsy moth populations. The gypsy moth is a serious pest of agriculture and forestry. Gypsy moth populations are controlled by Lymantria dispar Meyers multicapsid nuclear polyhedrosis virus (LdMNPV), in nature (Oberemok 2008b). Their results show that DNA insecticides based on DNA fragments of the anti-apoptosis gene of LdMNPV can be selective in action, and are not harmful to the tobacco hornworm [Manduca sexta (Linnaeus)] and black cutworm [Agrotis ipsilon (Hufnagel)]. The perspective of such an approach in practice is clearly seen because it provides the same effect with less effort. For example, instead of the expensive baculovirus preparation based on LdMNPV, it is possible to use small parts of the viral genome and get the same effect. Also, we recently found that treating baculovirus-infected gypsy moth caterpillars with sense and antisense DNA oligonucleotides of vIAP gene significantly increased insect mortality. Such treatments eventually lead to a more effective use of baculoviral preparations. The data of this work indicates that specific DNA oligonucleotides may interfere with expression of vIAP gene(s) to induce apoptosis in infected insects. This hypothesis is supported by the finding that the virus Oligo-IAPs affect the insect body mass and up-regulate the host pro-apoptotic genes (Oberemok, Laikova, Zaitsev, Skorokhod, Gushchin, unpublished data).

It is important to show that DNA insecticides will be safe for the environment. The scientific literature discusses how the potential hazards posed by RNA interference (RNAi)-based pesticides and genetically modified crops to non-target organisms include off-target gene silencing, silencing the target gene in unintended organisms, immune stimulation, and saturation of the RNAi machinery (Auer and Frederick 2009). Currently, there is not much evidence regarding possible side effects of DNA insecticides on the environment. We recently evaluated the possible side effects of the DNA insecticides on wheat (Triticum aestivum L.) and biomass of wheat sprouts (Oberemok et al. 2013b). We did not find negative effects of DNA insecticides on the plant during the investigation of some important biochemical parameters (concentration of glucose and activity of alkaline phosphatase). The use of insect-specific, short single-stranded DNA fragments as DNA insecticides, paves the way for the creation of "intellectual" insecticides that "think" before they act (Oberemok and Skorokhod 2014).

\section{Conclusions}

The evolution of insecticides will go on and new preparations will continue to appear on the market. The population of the world will continue to grow over the next 50 years and may reach 9 billion people. This will cause an increased global demand for food. More intensive food production is associated with more intensive use of pesticides, including insecticides. It is assumed that in 2050 , the use of pesticides will be 2.7 times higher than 
in 2000, which will put people and the environment in much greater danger (Sexton et al. 2007). We need to be prepared. In this situation, an agreeable interaction of scientists and the manufacturers of insecticides will lead to the selection of the most optimal solutions for the control of insect pests. The insecticides should be safe, affordable, and effective at the same time.

\section{References}

Alyokhin A. 2009. Colorado potato beetle management on potatoes: current challenges and future prospects. Fruit, Vegetable and Cereal Science and Biotechnology 3 (1): 10-19.

Auer C., Frederick R. 2009. Crop improvement using small RNAs: applications and predictive ecological risk assessments. Trends in Biotechnology 27 (11): 644-651.

Bate R. 2007. The rise, fall, rise, and imminent fall of DDT. American Enterprise Institute for Public Policy Research 14 (4): $1-9$.

Bahvalov S.A. 2001. Virozy Insects. Pathogens of Insects: Structural and Functional Aspects. Kryglui God, Moskva, Russia, $736 \mathrm{pp}$.

Broughton E. 2005. The Bhopal disaster and its aftermath: a review. Environmental Health 4: 6.

Casida J.E., Durkin K.A. 2013. Anticholinesterase insecticide retrospective. Chemico-Biological Interactions 203 (1): 221-225.

Chakoosari M.M.D. 2013. Efficacy of various biological and microbial insecticides. Journal of Biology and today's world 2 (5): 249-254.

Chiu E., Coulibaly F., Metcalf P. 2012. Insect virus polyhedra, infectious protein crystals that contain virus particles. Current Opinion in Structural Biology 22 (2): 234-240.

Dagaev M.V. 1997. Baleen aggressors or everything about the war on cockroaches. Iayza, Lan', Moskva, 112 pp.

Davies T.G., Field L.M., Usherwood P.N., Williamson M.S. 2007. DDT, pyrethrins, pyrethroids and insect sodium channels. IUBMB Life 59 (3): 151-162.

De Maagd R.A., Bravo A., Crickmore N. 2001. How Bacillus thuringiensis has evolved specific toxins to colonize the insect world. Trends in Genetics 17 (4): 193-199.

Federici B.A., Park H-W., Bideshi D.K. 2010. Overview of the basic biology of Bacillus thuringiensis with emphasis on genetic engineering of bacterial larvicides for mosquito control. Open Toxinology Journal 3 (1): 83-100.

Fire A., Xu S., Montgomery M., Kostas S., Driver S., Mello C. 1998. Potent and specific genetic interference by doublestranded RNA in Caenorhabditis elegans. Nature 391 (6669): 806-811.

Gordana G., Janko B. 2013. The synergy of xenobiotics in honey bee Apis mellifera: mechanisms and effects. Journal of Insect Physiology 58 (5): 613-620.

Goulson D. 2013. Review: An overview of the environmental risks posed by neonicotinoid insecticides. Journal of Applied Ecology 50 (4): 977-987.

Gu L., Knipple D.C. 2013. Recent advances in RNA interference research in insects: Implications for future insect pest management strategies. Crop Protection 45: 36-40.

Ignatowicz S., Wesołowska B. 1994. Potential of common herbs as grain protectans: repellent effect of herb extracts on the granary weevil, Sitophilus granarius (L). p. 790-794. In:
Proceedings of the 6th International Working Conference on Stored-Product Protection. Canaberra, Australia, 17-23 April 1994, 1274 pp.

Inceoglu A.B., Kamita S.G., Hammock B.D. 2006. Genetically modified baculoviruses: a historical overview and future outlook. Advances in Virus Research 68: 323-360.

Isman M.B. 2006. The role of botanical insecticides, deterrents and repellents in modern agriculture and an increasingly regulated world. Annual Review of Entomology 51 (1): 45-66.

Jeschke P., Nauen R., Schindler M., Elbert A. 2011. Overview of the status and global strategy for neonicotinoids. Journal of Agricultural and Food Chemistry 59 (7): 2897-2908.

Jehle J.A., Blissard G.W., Bonning B.C., Cory J.S., Herniou E.A., Rohrmann G.F., Theilmann D.A., Thiem S.M., Vlak J.M. 2006. On the classification and nomenclature of baculoviruses: A proposal for revision. Archives of Virology 151 (7): 1257-1266.

Kawai-Tayooka H., Kuramoto C., Orui K., Motoyama K., Kikuchi K., Kanegae T., Wada M. 2004. DNA interference: a simple and efficient gene-silencing system for high-throughput functional analysis in the fern Adiantum. Plant and Cell Physiology 45 (11): 1648-1657.

Khalil M.S. 2013 Abamectin and azadirachtin as eco-friendly promising biorational tools in integrated nematodes management programs. Journal of Plant Pathology and Microbiology 4 (4): 2-3.

Lu X., Yu Q., Binder G.K., Chen Z., Slepushkina T., Rossi J., Dropulic B. 2004. Antisense-mediated inhibition of human immunodeficiency virus (HIV) replication by use of an HIV type 1-based vector results in severely attenuated mutants incapable of developing resistance. Journal of Virology 78 (13): 7079-7088.

Majori G. 2012. Short history of malaria and its eradication in Italy. Mediterranean Journal of Hematology and Infectious Diseases 4 (1): 16.

Metalnikov S., Chorine V. 1929. On the infection of the gypsy moth and certain other insects with Bacterium thuringiensis. International Corn Borer Investigations. Scientific Reports 2: 60-61.

Miller L.K., Lingg A.J., Bulla L.A.J. 1983. Bacterial viral and fungal insecticides. Science 219 (4585): 715-721.

Moscardi F., De Souza M.L., de Batista Castro M.E., Moscardi M.L., Szewczyk B. 2011. Baculovirus pesticides: present state and future perspectives. p. 415-446. In: "Microbes and Microbial Technology" (I. Ahmad, F. Ahmad, J. Pichtel, eds.). Springer-Verlag, New York, USA, 516 pp.

Msangi S., Lyatuu E., Kweka E. 2011. Field and laboratory evaluation of bioefficacy of an insect growth regulator (Dimilin) as a larvicide against mosquito and housefly larvae. Journal of Tropical Medicine 2011: 1-8.

Nojumian F., Sabahi Q., Talaei-Hassanloui R., Darvishzadeh A. 2015. Sublethal effects of spirodiclofen on life table parameters of minute pirate bug Orius niger Wolff (Hemiptera: Anthocoridae). Journal of Entomology and Zoology Studies 3 (1): 227-232.

Oberemok V.V. 2008a. Method of elimination of phyllophagous insects from order Lepidoptera. Patent 36445 Ukraine, the applicant and the owner of the patent Taurida National V.I Vernadsky University. № u 20080674.

Oberemok V.V. 2008b. Proof of transovarial transmission of Lymantria dispar nucleopolyhedrovirus (Fam. Baculoviridae) 
with the RAPD-PCR method. Zhurnal Obshchej Biologii 69: 397-400. (in Russian)

Oberemok V.V. 2011. DNA markers in the study of the relationship between nuclear polyhedrosis virus and its host Lymantria dispar. Summary of Ph.D. thesis. Taras Shevchenko National University of Kyiv, Kyiv, Ukraine, 22 pp. (in Ukrainian)

Oberemok V.V., Simchuk A.P., Gninenko Yu.I. 2013a. DNA insecticides: application of the iap-2 gene single-stranded fragments from three different nucleopolyhedroviruses against second instar gypsy moth larvae. Universal Journal of Applied Science 1 (2): 33-37.

Oberemok V.V., Nyadar P.M., Zaytsev O.S., Levchenko N.N., Shiyntum H.N., Omelchenko O.V. 2013b. Pioneer evaluation of the possible side effects of the DNA insecticides on wheat (Triticum aestivum L.). International Journal of Biochemistry and Biophysics 1 (3): 57-63.

Oberemok V.V., Skorokhod O.A. 2014. Single-stranded DNA fragments of insect-specific nuclear polyhedrosis virus act as selective DNA insecticides for gypsy moth control. Pesticide Biochemistry and Physiology 113: 1-7.

Oberemok V.V., Nyadar P.M. 2015. Investigation of mode of action of DNA insecticides on the basis of LdMNPV IAP-3 gene. Turkish Journal of Biology 39: 258-264.

Oberemok V.V., Laikova K.V., Zaitsev A.S., Nyadar P.M., Shumskykh M.N., Gninenko Yu.I. 2015. DNA insecticides based on iap3 gene fragments of cabbage looper and gypsy moth nuclear polyhedrosis viruses show selectivity for non-target insects. Archives of Biological Sciences: 37. DOI: $10.2298 /$ ABS1412300370.

Popov S.Ya., Dorozhkina L.A., Kalinin V.A. 2003. Fundamentals of Chemical Plant Protection. Art-Lion, Moskva, 208 pp.

Qi S., Lummen P., Nauen R., Casida J. 2013. Diamide insecticide target site specificity in the Heliothis and Musca ryanodine receptors relative to toxicity. Journal of Agricultural and Food Chemistry 62 (18): 4077-4082.

Rosell G., Quero C., Coll J., Guerrero A. 2008. Biorational insecticides in pest management. Journal of Pesticide Science 33 (2): 103-121.
Sanchis V. 2011. From microbial sprays to insect-resistant transgenic plants: history of the biopesticide Bacillus thuringiensis. Agronomy for Sustainable Development 31 (1): 217-231.

Sexton S.S., Lei Z., Zilberman D. 2007. The economics of pesticides and pest control. International Review of Environmental and Resource Economics 1 (3): 271-326.

Simchuk A.P., Oberemok V.V., Ivashov A.V. 2012. Genetics of Interactions Among Moths, Their Host Plants and Enemies in Crimean Oak Forests, and its Perspective for Their Control. Nova Science Publisher, N.Y., USA, 286 pp.

Sohail A., Hamid F.S., Waheed A., Ahmed N., Aslam N., Zaman Q., Ahmed F., Islam S. 2012. Efficacy of different botanical materials against aphid Toxoptera aurantii on tea (Camellia sinensis L.) cuttings under high shade nursery. Journal of Materials and Environmental Science 3 (6): 1065-1070.

Symes C.B. 1952. Some recent progress in the study of Insecticides and their application for the control of vectors of disease. The Journal of the Royal Society for the Promotion of Health 72 (5): 498-514.

Szewczyk B., Hoyos-Carvajal L., Paluszek M., Skrzecz I., Lobode Souza M. 2006. Baculoviruses - re-emerging biopesticides. Biotechnology Advances 24 (2): 143-160.

Tarasevich L.M. 1985. Viruses of Insects. Izdatelstvo "Nauka", Moscow, Russia, 143 pp. (in Russian)

Viktorov A.V., Yurkiv V.A. 2003. Effect of ivermectin on function of liver macrophages. Bulletin of Experimental Biology and Medicine 136 (6): 569-571.

Wang Y., Zhang H., Li H., Miao X. 2011. Second-generation sequencing supply an effective way to screen RNAi targets in large scale for potential application in pest insect control. PLOS ONE 6 (4): 18644.

Weiss B., Davidkova G., Zhou L-W. 1999. Antisense RNA gene therapy for studying and modulating biological processes. Cellular and Molecular Life Science 55 (3): 334-358.

Yamamoto I. 1999. Nicotine to Nicotinoids: 1962 to 1997. p. 3-27. In: "Nicotinoid Insecticides and the Nicotinic Acetylcholine Receptor" (I. Yamamoto, J.E. Casida, eds.). Springer-Verlag, Tokyo, Japan, 270 pp. 